\title{
SPME/GC-MS analysis of volatile organic compounds from Origanum acutidens (Hand.-Mazz.) letsw. - An endemic species in Turkey
}

Yavuz Bülent Köse ${ }^{1, *}$, (D) Nagehan Saltan ${ }^{1}$ and (D) Mine Kürkçüoğlu ${ }^{2}$

${ }^{1}$ Department of Pharmaceutical Botany, Faculty of Pharmacy, Anadolu University, Eskişehir, TURKEY

${ }^{2}$ Department of Pharmacognosy, Faculty of Pharmacy, Anadolu University, 26470, Eskişehir, TURKEY

*Corresponding author. Email: ybkose@anadolu.edu.tr

Submitted: 05.04.2021; Accepted: 21.05.2021

\begin{abstract}
In this present study, it was aimed to determine the composition of the essential oil obtained by water distillation from the aerial parts of Origanum acutidens. The oil was analysed by GC-FID and GC/MS. Carvacrol (69.3\%), p-cymene (8.3\%), y-terpinene (6.3\%), $\beta$-caryophyllene (2.7\%) and borneol (2.2\%) were found as main constituents. In addition, headspace-solid phase microextraction using a Polydimethylsiloxane-Divinylbenzene (PDMS/DVB $-65 \mu \mathrm{m}$ ) fiber of $O$. acutidens was performed and analysed by GC-FID and GC/MS. The main components were identified as: carvacrol (44.0\%), $p$-cymene (25\%), $\curlyvee$-terpinene (8\%), $\beta$-caryophyllene (6.1\%) and borneol (6.1\%), respectively.
\end{abstract}

Keywords: Origanum acutidens, essential oil, carvacrol, Lamiaceae, HS-SPME

\section{Introduction}

The family Lamiaceae, which includes many plants with medicinal properties, is known for its richness of species, and most species are common in the Mediterranean. The family Lamiaceae is represented in Turkey by 782 taxa of which 346 taxa are endemic (44\%). 24 of 28 hybrids discovered in the flora of Turkey are endemic (Başer et Kırımer, 2007).

The genus Origanum L. is an important member of the Lamiaceae family, represented by 31 taxa, 10 of which are hybrids in Turkey (Baytop, 1999; Davis, 1982, Celep \& Dirmenci, 2017). Many studies were reported on the chemical composition and various biological activities of Origanum species, which are rich in essential oils.

Origanum species, traditionally are used as a sedative, antiseptic, against sore throat, diuretic, carminative and also in the treatment of gastrointestinal diseases and constipation (Baytop, 1999, Baser, 2008).

The endemic Origanum acutidens (Hand.-Mazz.) letsw. is a herbaceous perennial plant, flowering between June and August in Eastern Anatolia (Davis, 1982; letswaart , 1980) Growing on limestone and in noncalcareous soils between 1000-3000 m, sometimes in shady places, the plant needs very little moisture during the growing season In addition, $O$. acutidens, which can be widely used in urban landscape management, has showy, bright pink flowers and is an ornamental plant preferred due to its aromatic scent and its capacity to attract butterflies and bees (Karagoz and Karagoz, 2019). The species, which can grow up to $50 \mathrm{~cm}$ in length, is in hairless form, and its leaves bear intense odor (letswaart, 1980). O. acutidens, which is rich in carvacrol and thymol, is also rich in rosmarinic acid and therefore has antioxidant activity (Kordali et al., 2008). In addition, O. acutidens growing in the Eastern Anatolia region contains $>20 \%$ thymol (Karagoz and Karagoz, 2019; Kordali et al., 2008). Essential oil yields of $O$. acutidens range from 0.73 to $1.7 \%$ 
(Cosge et al., 2009; Cakmakcı et al., 2009). Essential oil compositions of $O$. acutidens were determined by several studies (Table 1).

Table 1. Previous studies on essential oils of $O$. acutidens

\begin{tabular}{|c|c|c|}
\hline Part distilled & Main components (\%) & Reference \\
\hline \multirow[t]{4}{*}{ Aerial parts } & Carvacrol (66.25\%) & (Baser et al.,1997) \\
\hline & p-Cymene (13.99\%) & \\
\hline & Bomeol (1.96\%) & \\
\hline & $\beta$-Caryophyllene (1.7\%) & \\
\hline \multirow[t]{5}{*}{ Aerial parts } & Carvacrol (87.0\%) & (Kordali et al., 2008) \\
\hline & p-Cymene (2.0\%) & \\
\hline & Linalool acetate (1.7\%) & \\
\hline & Borneol (1.6\%) & \\
\hline & $\beta$-Caryophyllene (1.3\%) & \\
\hline \multirow[t]{4}{*}{ Aerial parts } & Carvacrol (67.5\%) & (Figuérédo et al., 2006) \\
\hline & $p$-Cymene $(14.0 \%)$ & \\
\hline & Borneol (1.5\%) & \\
\hline & Terpinene 4-ol (1.4\%) & \\
\hline \multirow[t]{3}{*}{ Aerial parts } & Calvacrol (61.8 \%) & (Gulec et al., 2014) \\
\hline & p-Cymene (15.5\%) & \\
\hline & Thymol (12.7 \%) & \\
\hline \multirow[t]{5}{*}{ Aerial parts } & Carvacrol (86.99 \%) & (Tozlu et al., 2011) \\
\hline & p-Cymene (1.95 \%) & \\
\hline & Borneol (1.63 \%) & \\
\hline & Linalool acetate (1.65 \%) & \\
\hline & $\beta$-Caryophyllene (1.30\%) & \\
\hline \multirow[t]{5}{*}{ Aerial parts } & Carvacrol (76.2 \%) & (Figuérédo et al., 2012) \\
\hline & p-Cymene (7.4 \%) & \\
\hline & Borneol (3.2 \%) & \\
\hline & $\gamma$-Terpinene (1.38\%) & \\
\hline & Terpinene-4-ol (1.04\%) & \\
\hline \multirow[t]{6}{*}{ Aerial parts } & Carvacrol (61.8 \%) & (Gulec et al., 2014) \\
\hline & p-Cymene (15.5 \%) & \\
\hline & Thymol (12.7 \%) & \\
\hline & $\gamma$-Terpinene (1.4\%) & \\
\hline & Borneol (1.2\%) & \\
\hline & Hexadecanoic acid (1.2\%) & \\
\hline \multirow[t]{7}{*}{ Aerial parts and corollas } & Carvacrol (67.51\% and 52.33\%) & (Cosge et al., 2009) \\
\hline & $p$-Cymene (9.43\% and $17.51 \%)$ & \\
\hline & $\beta$-Caryophyllene (1.62 \% and $2.04 \%)$ & \\
\hline & Tymoquinone (3.80\% and $2.85 \%)$ & \\
\hline & Isoborneol (1.36\% and $2.21 \%)$ & \\
\hline & $\beta$-Thujone (1.31\% and $1.93 \%)$ & \\
\hline & $\beta$-Caryophyllene (1.62\% and $2.04 \%$ ) & \\
\hline \multirow[t]{6}{*}{ Aerial parts } & Carvacrol (65\%) & (Goze et al., 2010) \\
\hline & meta-Cymene (9.15 \%) & \\
\hline & trans-Caryophyllene (4.43\%) & \\
\hline & $\gamma$-Terpinene (3.54 \%) & \\
\hline & $\alpha$-Terpinene $(1.86 \%)$ & \\
\hline & Thymol (1.10\%) & \\
\hline
\end{tabular}




\begin{tabular}{|c|c|c|}
\hline \multirow[t]{5}{*}{ Herbal parts } & Carvacrol (72.0 \%) & (Sokmen et al., 2004) \\
\hline & p-Cymene (7.5\%) & \\
\hline & $\gamma$-Terpinene (5.3\%) & \\
\hline & $\beta$-Myrcene (1.7 \%) & \\
\hline & $\beta$-Caryophyllene (1.0\%) & \\
\hline \multirow[t]{4}{*}{ Aerial parts } & Carvacrol (61.69\%) & (Altıntas and Demirtas, 2017) \\
\hline & p-Cymene (17.32\%) & \\
\hline & $\gamma$-terpinene $(4.05 \%)$ & \\
\hline & Borneol (3.96\%) & \\
\hline \multirow[t]{4}{*}{ Aerial parts } & m-Cymene (39.2\%) & (Yilmaz et al., 2017) \\
\hline & $\tau$-Terpinene (3.4 \%) & \\
\hline & $\gamma$-Terpinene $(1.4 \%)$ & \\
\hline & allo-aromadendrene (24.8\%) & \\
\hline \multirow[t]{7}{*}{ Herbal parts } & Carvacrol (47.46\%) & (Cetin et al., 2011) \\
\hline & p-Cymene (22.22\%) & \\
\hline & Borneol (3.41\%) & \\
\hline & $\gamma$-Terpinene $(2.91 \%)$ & \\
\hline & $\beta$-Caryophyllene (2.70\%) & \\
\hline & Linalool (2.35\%) & \\
\hline & 3-Octanone (1.84\%) & \\
\hline
\end{tabular}

As seen in Table 1, carvacrol ratios of $O$. acutidens oils were reported as: $87.0 \%$ (Kordali et al., 2008; Tozlu et al., 2011); 76.2\% (Figueredo et al., 2012); 67.5\% (Cosge et al., 2009); 66.3\% (Baser et al., 1997) and 65.0\% (Goze et al.,2010). In addition, the essential oil obtained from $O$. acutidens was the main component of the oil, carvacrol followed by $p$-cymene, while other important components were borneol, thymol, $\beta$ caryophyllene, $\gamma$-terpinene, linalool, linalyl acetate, $\beta$-myrcene, 3 -octanone and thymol. Aerial parts of the plants were often subjected to distillation procedures by different researchers. In general, monoterpenes were the main groups in essential oils.

The SPME method has some advantages over traditional methods. SPME combines sampling, extraction, concentration and sample entry in a single solvent-free stage. Analytes in the sample are extracted directly on the extraction fiber. The method saves preparation time and disposal costs and can improve detection limits (Vas and Vekey, 2004).

The aim of this study is to reveal the essential oil content of $O$. acutidens by distillation as well as to determine the differences in volatile organic compound distribution using HS-SPME analysis.

\section{Materials and Methods}

\section{Plant material and isolation of essential oil}

O. acutidens was collected from Erzurum province ( $40^{\circ} 9^{\prime} 33^{\prime \prime} \mathrm{K}, 41^{\circ} 2^{\prime} 52^{\prime \prime} \mathrm{D}, 2030 \mathrm{~m}$.) of Turkey during flowering in July 2019. Voucher specimens are stored in the Herbarium of the Faculty of Pharmacy of Anadolu University, in Eskisehir, Turkey (ESSE 15529). Essential oil was obtained from the dried plant samples by hydrodistilation for 3 hours with the Clevenger-type apparatus and hydrodistillation of $O$. acutidens with a yield of $0.8 \%(w / v)$ of essential oil.

\section{Analysis of the essential oil}

The oil was analyzed by capillary GC and GC/MS using a Agilent GC-MSD system. 


\section{Headspace-solid phase microextraction (HS-SPME) analysis}

$30^{\circ} \mathrm{C}$ and 30 min sampling was carried out on plant materials using SPME fibre PolydimethylsiloxaneDivinylbenzene (PDMS/DVB - 65 $\mu \mathrm{m}$ ) - Blue (supplied by Supelco Bellefonte, USA). The fiber was directly desorbed at $250 \circ \mathrm{C}$ for $10 \mathrm{~min}$. in GC/MS.

\section{Gas chromatography (GC) and gas chromatography - mass spectrometry (GC/MS) analysis}

\section{GC-MS conditions}

The oil was analyzed by capillary GC/MS using an Agilent GC-MSD system (Agilent Technologies Inc., Santa Clara, CA). HP-Innowax FSC column (Hewlett-Packard-HP, U.S.A.) $(60 \mathrm{~m} \times 0.25 \mathrm{~mm}$ i.d., with $0.25 \mu \mathrm{m}$ film thickness) was used for separation of components in the oil and helium as a carrier gas $(0.8 \mathrm{~mL} / \mathrm{min})$. The GC oven temperature was kept at $60^{\circ} \mathrm{C}$ for $10 \mathrm{~min}$ and programmed to $220^{\circ} \mathrm{C}$ at a rate of $4^{\circ} \mathrm{C} / \mathrm{min}$, and kept constant at $220^{\circ} \mathrm{C}$ for $10 \mathrm{~min}$ and then programmed to $240^{\circ} \mathrm{C}$ at a rate of $1^{\circ} \mathrm{C} / \mathrm{min}$. The split flow was adjusted at 40:1 split ratio (at splitless mode for SPME). The injector temperature was set at $250^{\circ} \mathrm{C}$. Mass spectra were taken at $70 \mathrm{eV}$ with the mass range $\mathrm{m} / \mathrm{z}$ 35-450.

\section{GC conditions}

The GC analysis was done with Agilent 6890N GC system fitted with a FID detector set at a temperature of $300^{\circ} \mathrm{C}$. To obtain the same elution order with GC-MS, simultaneous auto-injection was done on a duplicate of the same column applying the same operational conditions. Relative percentage amounts of the separated compounds were calculated from FID chromatograms by using Agilent ChemStation Plus ${ }^{\circ}$ software with peak integration process.

\section{Identification of compounds}

Identification of essential oil components were performed by comparison of their mass spectra with those in the Baser Library of Essential Oil Constituents, Wiley GC/MS Library, Adams Library, MassFinder Library and confirmed by comparison of their retention indices. A homologous series of $n$-alkanes (C8-C24) were used as the reference points in calculation of relative retention indices (RRI). The relative percentages of the separated compounds were calculated from FID chromatograms. The analysis results are expressed as mean percentage as listed in Table 2 and Table 3.

\section{Results and Discussion}

O. acutidens oil yield was $0.8 \%$. Twenty four compounds were identified in oil of the aerial parts representing $99.7 \%$ of the 0 . acutidens essential oil. The main components of the oil were carvacrol (69.3\%) and $p$-cymene (8.3\%). As seen in Table 2, the terpenoids consist of the main portion of $O$. acutidens essential oil and oxygenated monoterpenes (73.5\%) were the main group of constituents, followed by monoterpene hydrocarbons (19.6\%), sesquiterpene hydrocarbons $(5.0 \%)$, oxygenated sesquiterpenes $(0.3 \%)$ and others (1.3\%). 
Table 2. The composition of the essential oil of $O$. acutidens

\begin{tabular}{|c|c|c|c|c|}
\hline No & RRI & Compounds & $\%$ & IM \\
\hline 1 & 1032 & $\alpha$-Pinene & 0.6 & $t_{R}, M S$ \\
\hline 2 & 1035 & $\alpha$-Thujene & 1.0 & MS \\
\hline 3 & 1076 & Camphene & 0.5 & $t_{R}, M S$ \\
\hline 4 & 1174 & Myrcene & 1.7 & $t_{R}, M S$ \\
\hline 5 & 1188 & $\alpha$-Terpinene & 1.2 & $t_{R}, M S$ \\
\hline 6 & 1255 & $\mathrm{y}$-Terpinene & 6.3 & $t_{R}, M S$ \\
\hline 7 & 1265 & 3-Octanone & 0.8 & $t_{R}, M S$ \\
\hline 8 & 1280 & $p$-Cymene & 8.3 & $t_{R}, M S$ \\
\hline 9 & 1452 & 1-Octen-3-ol & 0.5 & $t_{R}, M S$ \\
\hline 10 & 1474 & trans-Sabinene hydrate & 0.5 & $t_{R}, M S$ \\
\hline 11 & 1556 & cis-Sabinene hydrate & 0.3 & $t_{R}, M S$ \\
\hline 12 & 1611 & Terpinen-4-ol & 0.8 & $t_{R}, M S$ \\
\hline 13 & 1612 & $\beta$-Caryophyllene & 2.7 & $t_{R}, M S$ \\
\hline 14 & 1628 & Aromadendrene & 0.2 & MS \\
\hline 15 & 1630 & trans-Dihydrocarvone & 0.1 & $t_{R}, M S$ \\
\hline 16 & 1634 & cis-Dihydrocarvone & 0.1 & $t_{R}, M S$ \\
\hline 17 & 1687 & $\alpha$-Humulene & 0.1 & $t_{R}, M S$ \\
\hline 18 & 1708 & Ledene & 0.2 & MS \\
\hline 19 & 1719 & Borneol & 2.2 & $t_{R}, M S$ \\
\hline 20 & 1726 & Germacrene D & 0.7 & MS \\
\hline 21 & 1755 & Bicyclogermacrene & 1.1 & $t_{R}, M S$ \\
\hline 22 & 2144 & Spathulenol & 0.3 & $t_{R}, M S$ \\
\hline 23 & 2198 & Thymol & 0.2 & $t_{R}, M S$ \\
\hline \multirow[t]{7}{*}{24} & 2239 & Carvacrol & 69.3 & $t_{R}, M S$ \\
\hline & & Monoterpene hydrocarbons & 19.6 & \\
\hline & & Oxygenated monoterpenes & 73.5 & \\
\hline & & Sesquiterpene hydrocarbons & 5.0 & \\
\hline & & Oxygenated sesquiterpenes & 0.3 & \\
\hline & & Others & 1.3 & \\
\hline & & Total (\%) & 99.7 & \\
\hline
\end{tabular}

RRI: Relative retention indices experimentally calculated against $n$-alkanes; IM: Identification Method: $t_{R}$, Identification based on comparison with co-injected with standards on a HP Innowax column; MS, identified on the basis of computer matching of the mass spectra with those of the in-house Baser Library of Essential Oil Constituents, Adams, MassFinder and Wiley libraries (Adams, 2007; Hochmuth, 2008; McLafferty and Stauffer, 1989).

The volatile compounds were also obtained by the HS-SPME method and analyzed by GC-FID and GC/MS. The volatiles were trapped by SPME in a dynamic headspace set up. A blue Polydimethylsiloxane/Divinylbenzene (PDMS/DVB) fibre was used for $30 \mathrm{~min}$. Seventeen volatile compounds were identified in the aerial parts representing $100.0 \%$ of the total headspace volatiles. Main components were identified as carvacrol (44\%), $p$-cymene (25.0\%), $\checkmark$-terpinene (8.0\%), $\beta$-caryophyllene (6.1\%) and borneol (6.1\%) (Table 3). 
Table 3. Headspace volatiles of $O$. acutidens

\begin{tabular}{|c|c|c|c|c|}
\hline No & $\mathbf{R} \mathbf{R} \mathbf{I}^{\mathbf{a}}$ & Compounds & $\%$ & IM \\
\hline 1 & 1174 & Myrcene & 2.0 & $t_{R}, M S$ \\
\hline 2 & 1188 & $\alpha$-Terpinene & 2.3 & $t_{R}, M S$ \\
\hline 3 & 1255 & $y$-Terpinene & 8.0 & $t_{R}, M S$ \\
\hline 4 & 1265 & 3-Octanone & 0.8 & $t_{R}, M S$ \\
\hline 5 & 1280 & $p$-Cymene & 25.0 & $t_{R}, M S$ \\
\hline 6 & 1393 & 3-Octanol & 0.4 & MS \\
\hline 7 & 1452 & 1-Octen-3-ol & 1.3 & $t_{R}, M S$ \\
\hline 8 & 1474 & trans-Sabinene hydrate & 0.5 & $\mathrm{t}_{\mathrm{R}}, \mathrm{MS}$ \\
\hline 9 & 1556 & cis-Sabinene hydrate & 0.3 & $t_{R}, M S$ \\
\hline 10 & 1611 & Terpinen-4-ol & 1.1 & $t_{R}, M S$ \\
\hline 11 & 1612 & $\beta$-Caryophyllene & 6.1 & $t_{R}, M S$ \\
\hline 12 & 1628 & Aromadendrene & 1.1 & MS \\
\hline 13 & 1630 & trans-Dihydrocarvone & 0.5 & $t_{R}, M S$ \\
\hline 14 & 1634 & cis-Dihydrocarvone & 0.2 & $t_{R}, M S$ \\
\hline 15 & 1719 & Borneol & 6.1 & $t_{R}, M S$ \\
\hline 16 & 2198 & Thymol & 0.3 & $t_{R}, M S$ \\
\hline \multirow[t]{2}{*}{17} & 2239 & Carvacrol & 44.0 & $t_{R}, M S$ \\
\hline & & Total (\%) & 100.0 & \\
\hline
\end{tabular}

RRI: Relative retention indices experimentally calculated against $n$-alkanes; IM: Identification Method: $t_{R}$, Identification based on comparison with co-injected with standards on a HP Innowax column; MS, identified on the basis of computer matching of the mass spectra with those of the in-house Baser Library of Essential Oil Constituents, Adams, MassFinder and Wiley libraries (Adams, 2007; Hochmuth, 2008; McLafferty and Stauffer, 1989).

Figure 1. General view of 0 . acutidens

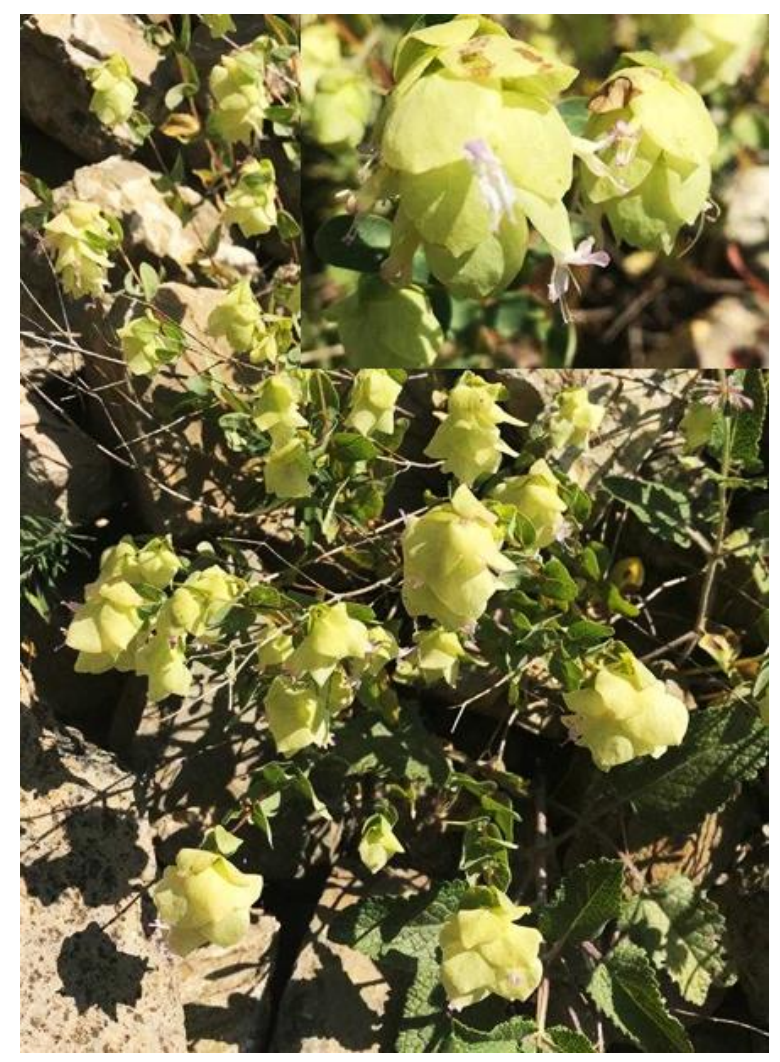


In this study, the essential oil content of the hydrodistilled herbal parts of $O$. acutidens was revealed and the differences in the volatile organic compound distribution were determined by HS-SPME analysis. Twenty-four components constituting $99.1 \%$ of the total components detected were characterized while seventeen volatile components were identified representing $100.0 \%$ of the total headspace volatiles. Our results indicated that carvacrol was the main constituent (44.0-SPME; \%-69.3\%-EO) in the oil of $O$. acutidens.

The essential oil composition of O. acutidens was previously reported (Baser et al., 1997; Caglar et al., 2007; Figuérédo et al., 2006; Kordali et al., 2008; Sokmen et al., 2004; Yildirim et al., 2005 ), where it was shown that carvacrol (66.0-72.0\%) and p-cymene (7.5-14.0\%) were the major components of the oil. In another study, Gulec et al., (2014) reported that the 0 . acutidens essential oil and its aromatic monoterpene components showed potent antibacterial activity against pathogenic bacterial strains. In addition, carvacrol (61.8\%), p-cymene (15.5\%) and thymol (12.7\%) that possessed antimicrobial activity were found as the major components. Findings were almost in agreement with the previous studies.

Although it was stated in previous studies on Origanum species that their essential oils are rich in carvacrol, thymol, $y$-terpinene and $p$-cymene and carvacrol is the main component (Bouchra et al., 2003; Daouk et al., 1995; Esen et al., 2007; Mueller-Riebau et al., 1995; Soković et al., 2002; Soylu et al., 2006), in some Origanum oils belonging to different genotypes, thymol had a higher percentage than carvacrol (Bendahou et al., 2008; Daferera et al., 2003; Esen et al., 2007). When our findings compared with previous data, carvacrol content in 0 . acutidens (69.3\%-44.0\%) was much higher than thymol (0.2\%-0.3\%). Other volatile components were similar to studies in the literature. Some slight differences among the volatile components in our study and previous studies were observed (Table 1).

Since the study is aimed to determine the natural scent of $O$. acutidens; HS-SPME was made at room temperature, the ratio of natural fragrance compounds given by the plant to the environment were determined and the amount of carvacrol was found to be lower than in essential oil.

Recent researches have revealed that carvacrol is very effective against cancer cells. It has been reported to be effective against prostate cancer cells, lung cancer cells, oral cancer cells and brain tumors (Junk et al., 2018; Liang \& Lu, 2012; Ozkan \& Erdogan, 2012; Baser, 2008). Therefore, the species with high carvacrol content like $O$. acutidens are important not only commercially but also for biological activity.

\section{CONFLICTS OF INTEREST}

The authors have no conflicts of interest to declare.

\section{REFERENCES}

Adams, R. P. (2007). Identification of essential oil components by gas chromatography/mass spectrometry Carol Stream, (IL): : Allured.

Altuntas, F. O., \& Demirtas, I. (2017). Real-time cell analysis of the cytotoxicity of Origanum acutidens essential oil on HT-29 and HeLa cell lines. Turkish Journal of Pharmaceutical Sciences, 14(1), 29.

Baser, K.H.C. (2008). Biological and Pharmacological Activities of Carvacrol and Carvacrol Bearing Essential Oils, K.H.C. Baser, Curr. Pharm. Design, 14, 3106-3120.

Baser, K., Tümen, G., \& Duman, H. (1997). Essential oil of Origanum acutidens (Hand.-Mazz.) letswaart. Journal of Essential Oil Research, 9(1), 91-92.

Baser, K.H.C. \& Kırımer, N. (2017). Essential Oils of Anatolian Lamiaceae - An Update, Lamiaceae 2017 Abstracts, Natural Volatiles Essential Oils, 4, 2-8. 
Baytop, T. (1999). Therapy with medicinal plants in Turkey; today and in future. İstanbul: Istanbul University Press.

Bendahou, M., Muselli, A., Grignon-Dubois, M., Benyoucef, M., Desjobert, J.-M., Bernardini, A.-F., \& Costa, J. (2008). Antimicrobial activity and chemical composition of Origanum glandulosum Desf. essential oil and extract obtained by microwave extraction: Comparison with hydrodistillation. Food Chemistry, 106(1), 132-139.

Bouchra, C., Achouri, M., Hassani, L. I., \& Hmamouchi, M. (2003). Chemical composition and antifungal activity of essential oils of seven Moroccan Labiatae against Botrytis cinerea Pers: Fr. Journal of Ethnopharmacology, 89(1), 165169.

Caglar, O., Calmaşur, OO, Aslan, I., \& Kaya, O. (2007). Insecticidal effect of essential oil of Origanum acutidens against several stored product pests. Fresenius Environmental Bulletin, 16, 1395-1400.

Cakmakci, R., Erdogan, Y., Erdogan, U., Kotan, R., \& Mete, E. (2009). Research on essential oil content and components of wild ecotype Origanum acutidens in different ecologies of the ispir Region. Paper presented at the International Rural Development Symposium, İspir, Erzurum, Turkey, 166-171.

Cetin, B., Cakmakci S., \& Cakmakci, R. (2011). The investigation of antimicrobial activity of thyme and oregano essential oils. Turkish Journal of Agriculture and Forestry, 35(2), 145-154.

Celep, F. \& Dirmenci, T. (2017). Systematic and Biogeographic Overview of Lamiaceae in Turkey. Nat. Volatiles and Essent. Oils, 4(4) 14-27.

Cosge, B., Turker, A., Ipek, A., \& Gurbuz, B. (2009). Chemical compositions and antibacterial activities of the essential oils from aerial parts and corollas of Origanum acutidens (Hand.-Mazz.) letswaart, an endemic species to Turkey. Molecules, 14(5), 1702-1712.

Daferera, D. J., Ziogas, B. N., \& Polissiou, M. G. (2003). The effectiveness of plant essential oils on the growth of Botrytis cinerea, Fusarium sp. and Clavibacter michiganensis subsp. michiganensis. Crop Protection, 22(1), 39-44.

Daouk, R. K., Dagher, S. M., \& Sattout, E. J. (1995). Antifungal activity of the essential oil of Origanum syriacum L. Journal of Food Protection, 58(10), 1147-1149.

Davis, P. (1982). Flora of Turkey and East Aegean Islands Vol. 7. Edinburg: Edinburg University Press

Esen, G., Azaz, A. D., Kurkcuoglu, M., Baser, K.H.C., \& Tinmaz, A. (2007). Essential oil and antimicrobial activity of wild and cultivated Origanum vulgare L. subsp. hirtum (Link) letswaart from the Marmara region, Turkey. Flavour and Fragrance Journal, 22(5), 371-376.

Figuérédo, G., Chalchat, J.-C., \& Pasquier, B. (2006). Studies of Mediterranean oregano populations IX: chemical composition of essential oils of seven species of oregano of various origins. Journal of Essential Oil Research, 18(4), 411-415.

Figueredo, G., Musa Özcan, M., Chalchat, J. C., Bagci, Y., \& Chalard, P. (2012). Chemical composition of essential oil of Hyssopus officinalis L. and Origanum acutidens. Journal of Essential Oil Bearing Plants, 15(2), 300-306.

Goze, I., Alim, A., Cetinus, S. A., Cetin, A., Durmus, N., Atas, A. T., \& Vural, N. (2010). In vitro antimicrobial, antioxidant, and antispasmodic activities and the composition of the essential oil of Origanum acutidens (Hand.-Mazz.) letswaart. Journal of Medicinal Food, 13(3), 705-709.

Gulec, A. K., Erecevit, P., Yuce, E., Arslan, A., Bagci, E., \& Kirbag, S. (2014). Antimicrobial Activity of the Methanol Extracts and Essential Oil with the Composition of Endemic Origanum acutidens (Lamiaceae). Journal of Essential Oil Bearing Plants, 17(2), 353-358.

Hochmuth, D. H. (2008). MassFinder-4: Hochmuth Scientific Consulting: Hamburg, Germany

letswaart, J. H. (1980). A taxonomic revision of the genus Origanum (Labiatae), LaHague: Leiden University Press. 
Jung, C. Y., Kim, S. Y., Lee, C. (2018). Carvacrol targets AXL to inhibit cell proliferation and migration in non-small cell lung cancer cells. Anticancer Research, 38(1), 279-286.

Karagoz H and Karagoz F. P. (2019). Areas of Utilization of Origanum acutidens (Hand.-Mazz.) letswaart and Carvacrol. International Journal of Current Research and Academic Review, 7(2), 46-55.

Kordali, S., Cakir, A., Ozer, H., Cakmakci, R., Kesdek, M., \& Mete, E. (2008). Antifungal, phytotoxic and insecticidal properties of essential oil isolated from Turkish Origanum acutidens and its three components, carvacrol, thymol and p-cymene. Bioresource Technology, 99(18), 8788-8795.

Liang, W Z., Lu, C H. (2012). Carvacrol-induced $\left[\mathrm{Ca}^{2+}\right]$ i rise and apoptosis in human glioblastoma cells. Life Sciences, 90(17-18), 703-711.

McLafferty, F. W., \& Stauffer, D. B. (1989). The Wiley/NBS registry of mass spectral data (Vol. 1): Wiley New York.

Mueller-Riebau, F., Berger, B., \& Yegen, O. (1995). Chemical composition and fungitoxic properties to phytopathogenic fungi of essential oils of selected aromatic plants growing wild in Turkey. Journal of Agricultural and Food Chemistry, 43(8), 2262-2266.

Ozkan, A., Erdogan, A. (2012). A comparative study of the antioxidant/prooxidant effects of carvacrol and thymol at various concentrations on membrane and DNA of parental and drug resistant H1299 cells. Natural Product Communications, 7(12), 1557-1560.

Sokmen, M., Serkedjieva, J., Daferera, D., Gulluce, M., Polissiou, M., Tepe, B., . . . Sokmen, A. (2004). In vitro antioxidant, antimicrobial, and antiviral activities of the essential oil and various extracts from herbal parts and callus cultures of Origanum acutidens. Journal of Agricultural andFood Chemistry, 52(11), 3309-3312.

Soković, M., Tzakou, O., Pitarokili, D., \& Couladis, M. (2002). Antifungal activities of selected aromatic plants growing wild in Greece. Food/Nahrung, 46(5), 317-320.

Soylu, E. M., Soylu, S., \& Kurt, S. (2006). Antimicrobial activities of the essential oils of various plants against tomato late blight disease agent Phytophthora infestans. Mycopathologia, 161(2), 119-128.

Tozlu, E., Cakir, A., Kordali, S., Tozlu, G., Ozer, H., \& Akcin, T. A. (2011). Chemical compositions and insecticidal effects of essential oils isolated from Achillea gypsicola, Satureja hortensis, Origanum acutidens and Hypericum scabrum against broadbean weevil (Bruchus dentipes). Scientia horticulturae, 130(1), 9-17.

Vas, G. \& Vekey, K. (2004). Solid-phase microextraction: a powerful samplepreparation tool prior to mass spectrometric analysis. Journal Of Mass Spectrometry, 39, 233-254.

Yıldırım, E., Kesdek, M., Aslan, İ., Calmaşur, O., \& Sahin, F. (2005). The effects of essential oils from eight plant species on two pests of stored product insects. Fresenius Environmental Bulletin, 14, 23-27.

Yılmaz, H., Carikci, S., Kılıc, T., Dirmenci, T., Arabacı, T., \& Goren, A. C. (2017). Screening of chemical composition, antioxidant and anticholinesterase activity of section Brevifilamentum of Origanum (L.) species. Records of Natural Products, 11(5), 439-455. 